\title{
Iris Metastasis of Esophageal Cancer
}

\author{
Toshiharu Tatai, Shigeru Sasaki, Nodoka Sekiguchi and Tomonobu Koizumi
}

Key words: eye metastasis, squamous cell carcinoma

(Intern Med 54: 1941, 2015)

(DOI: 10.2169/internalmedicine.54.4671)

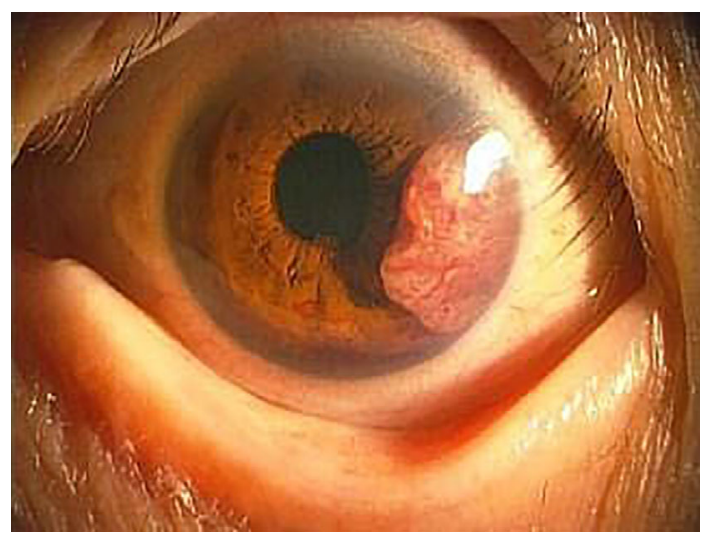

Picture 1.

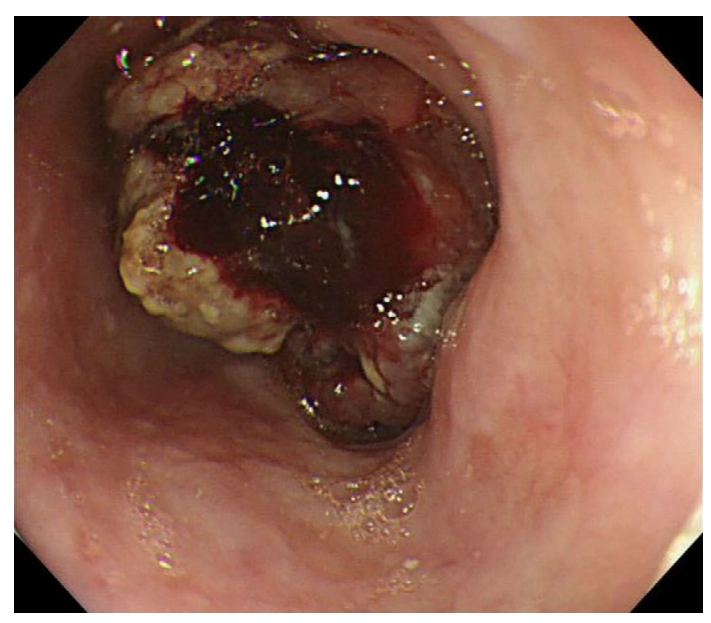

Picture 3.

A 75-year-old man was referred to the Department of Ophthalmology at our hospital due to pain in his left eye. An ophthalmologic examination revealed a tumor on the surface of the left iris at 3 o'clock (Picture 1), suggesting a metastatic malignant disease. ${ }^{18}$ F-Fluorodeoxy glucose positron emission tomography (FDG-PET) revealed abnormal uptake in the esophagus, liver, and lymph nodes as well as a
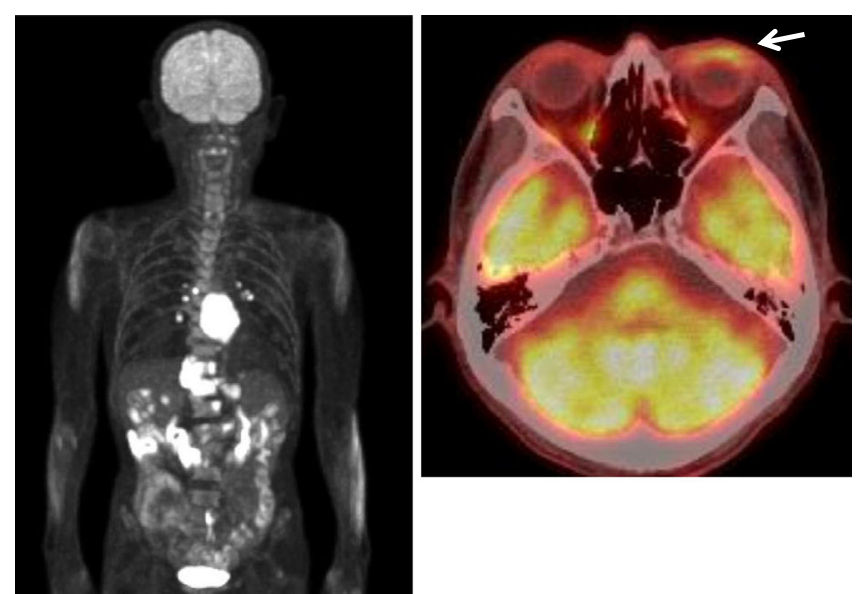

Picture 2.

lesion in the left eye (Picture 2). An endoscopic examination revealed type I advanced esophageal cancer $35 \mathrm{~cm}$ from the dental arches (Picture 3), and the histological findings indicated squamous cell carcinoma. Based on these findings, we diagnosed the patient with iris metastasis of esophageal cancer and the patient received radiotherapy for the left eye and esophagus. The tumor in the left eye reduced in size and the pain was also alleviated after radiotherapy, however, the patient's vision failed to improve. Metastasis of the iris in patients with esophageal cancer is extremely rare $(1,2)$.

The authors state that they have no Conflict of Interest (COI).

\section{References}

1. Lee WB, Sy HM, Filip DJ, Grossniklaus HE. Metastatic esophageal adenocarcinoma presenting in the iris. Am J Ophthalmol 144: 477-479, 2007.

2. Shields CL, Manquez ME, Ehya H, Mashayekhi A, Danzig CJ, Shields A. Fine-needle aspiration biopsy of iris tumors in 100 consecutive cases: technique and complications. Ophthalmology 113: 2080-2086, 2006.

Department of Comprehensive Cancer Therapy, Shinshu University School of Medicine, Japan

Received for publication December 8, 2014; Accepted for publication December 10, 2014

Correspondence to Dr. Tomonobu Koizumi, tomonobu@shinshu-u.ac.jp

(C) 2015 The Japanese Society of Internal Medicine Journal Website: http://www.naika.or.jp/imonline/index.html 